\title{
Keratocystic odontogenic tumor: A retrospective study of 64 cases
}

\section{Keratokistik odontojenik tümör: 64 vakalık retrospektif çalışma}

\author{
Cemal AKAY Ayhan TETIK Mert ZEYTINOĞLU \\ Ege University, Faculty of Dentistry, Department of Oral and Maxillofacial Surgery, Izmir, Turkey
}

\begin{abstract}
Aim: The purpose of this retrospective study was to evaluate the clinicopathological features of 64 patients with keratocystic odontogenic tumor (KCOT).

Materials and Methods: The patients ranged in age at the time of diagnosis from 8 to 74 years (mean: $38.20 \pm$ 16.71). Postoperative follow-up period was $3-8$ years (mean time $4.76 \pm 1.10$ ). This research was carried out on panoramic radiographs and histopathological samples. Data such as gender, age, treatment methods, location of the tumor, presence of impacted teeth and its histological features were subjected to descriptive statistical analyses with the statistical software program.
\end{abstract}

Results: Of the 64 analyzed cases of KCOT, $68.8 \%$ of them were men and $31.2 \%$ were females (male-to-female ratio was $2.2: 1)$. It was observed that KCOT peaked in the third and fifth decade of life $(23.4 \%-20.3 \%)$. The incidence of KCOT was higher in the mandible than in the maxilla $(76.6 \%-23.4 \%)$. There was recurrence in nine out of 64 subjects $(14.1 \%)$ in the follow-up period. The recurrence was more often found in posterior mandible. It is noteworthy that in 9 recurrent subjects, 7 lesions were parakeratotic and 4 lesions were associated with daughter cysts.

Conclusion: Although there are several studies about KCOT in the literature, the choice of treatment modalities remains controversial. In recurrent subjects, more aggressive therapy approaches should be considered. Periodic controls and aggressive treatment approaches may be effective in the prevention of recurrences.

Keywords: Keratocystic odontogenic tumor, parakeratinization, recurrence.

\section{Öz}

Amaç: Bu retrospektif çalışma da, keratokistik odontojenik tümör (KOT) tanısı konmuş 64 hastanın klinikopatolojik özelliklerinin değerlendirilmesi amaçlanmıştır.

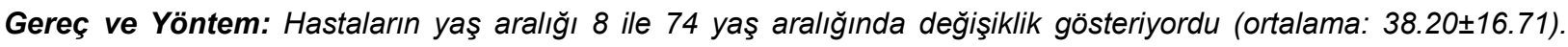

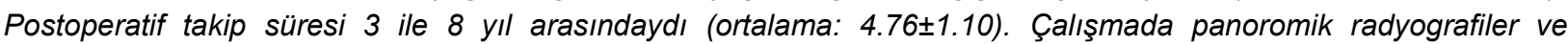
histopatolojik örnekler değerlendirildi. Cinsiyet, yaş, tedavi yöntemleri, tümörün lokalizasyonu, gömülü diş varlığı ve tümörün histolojik özellikleri gibi veriler istatistiksel yazılım programı yardımı ile tanımlayıcı istatistiksel analizlere tabi tutuldu.

Bulgular: 64 KOT vakası incelendiğinde olguların\%68.8'ini erkekler \%31.2'sini ise kadınlar oluşturuyordu (kadın/erkek oranı 1:2.2). KOT'un hayatın üçüncü ve beşinci on yılı içinde pik yaptığı bulundu (\%23.4-\%20.3). KOT insidansı mandibulada maksillaya oranla daha yüksekti (\% 76.6-\% 23.4). Takip sürecinde 64 vakanın 9 tanesinin (\%14.1) nüks ettiği tespit edildi. Nüks vakalarının büyük çoğunluğu posterior mandibulada tespit edildi. Dikkat çekici şekilde 9 nüks vakasının 7'si parakeratotik tipte olup 4 tanesi daughter kist ile ilkişkiliydi.

Sonuç: Literatürde KOT ile ilgili birçok çalışma olmasına rağmen tedavi stratejilerinin seçimi halan tartışmalıdır. Rekürrens gösteren vakalarda daha agresif tedavi yöntemlerin seçimi gerekmektedir. Periodik kontroller ve agresif tedavi yaklaşımları rekürrensin önlenmesinde etkili olabilir.

Anahtar Sözcükler: Keratokistik odontojenik tümör, parakeratinizasyon, rekürrens.

Corresponding Author: Cemal AKAY

Ege University, Faculty of Dentistry, Department of Oral and

Maxillofacial Surgery, Izmir, Turkey

Received: 17.06.2014 Accepted: 18.07.2014 


\section{Introduction}

Keratocystic odontogenic tumor (KCOT), formerly known as odontogenic keratocyst (OKC), is a benign, uni or multicyctic, intraosseous tumor of odontogenic origin with a characteristic lining of parakeratinized stratified squamous epithelium $(1,2)$. The first description of OKC was published in 1956 by Philipsen (2-4). It has long been of particular interest because of its potential for locally destructive behavior, its recurrence rate, and its tendency for multiplicity, particularly its current treatment modalities $(5,6)$. The role of mutation of the PTCH gene in the etiology of KCOTs resulted in reclassification of this lesion as a neoplasm in the WHO classification of head and neck tumors in 2005 and its renaming as KCOT (5). KCOTs often occur in the mandibular ramus and angle region but rarely in other mandibular regions and in the maxillary region (7,8). Radiographically, KCOTs present as well defined radiolucent lesions with smooth and usually corticated margins. These lesions may be either multilocular or unilocular on radiography. Generally, KCOTs may occur with impacted tooth. A male predominance has been reported for KCOT in previous studies. It mostly occurs in the second and third decades of lifes $(9,10)$.

Generally, KCOTs are solitary lesions; however, in 5$10 \%$ patients, where KCOTs appear as manifestation of Gorlin syndrome, they can be seen in multiple form $(9,11)$. There is no consensus on the uniform treatment plan in the current literatures (12).

In this retrospective study, we investigated 64 KCOTs in Turkish patients who were treated at Ege University School of Dentistry, Department of Oral and Maxillofacial Surgery, over a period of 8 years. We focused on patient gender and age, tumor location, its histological features, the applied treatment method and impacted teeth as well as the recurrence rate.

\section{Materials and Methods}

A retrospective study was made of cases of KCOTs recorded at our institution from January 2006 to January 2014. The review was performed in 64 cases of KCOT. This study based on histopathological reports regarding cases of KCOT diagnosed at our Oral Pathology Department, using the diagnostic criteria outlined by the 2005 World Health Organization Classification of Head and Neck Tumors (5). Patients associated with the signs of NBCCS were excluded from this study. Before the initial biopsy, informed consent form was obtained from all patients. All subjects were evaluated clinically and radiographically for any recurrence at a regular basis during the observation periods. The frequency of follow up was every month during the first year after surgery followed by 3 months from the following year. Routinely, panoramic radiographs were taken at 6 and 12 in the first post-operative year followed by at least once every year. With regard to site distribution, the maxilla and the mandible were divided into three anatomic regions: anterior, posterior and extend location. The anterior region was defined as the canine-to-canine segment. The posterior region was defined as the premolar and molar region, including the ramus of the mandible. The extend location was defined as involving both the anterior and posterior segments. The variables included patient age and gender, tumour location, histopatological findings, the applied treatment modalities and tumor recurrence.

Data were subjected to descriptive statistical analyses with the SPSS version 15.0 statistical software package (SPSS Inc., Chicago, USA). Descriptive statistics were performed for continuous variables as mean \pm standart deviation. For expressing variables, number of cases and $\%$ were used.

\section{Results}

During a 8-year period, totally 64 tumors collected and reevaluated and checked to be KCOT. Forty-four $(68.8 \%)$ occured in males and twenty $(31.2 \%)$ in females; the male to female ratio was 2.2:1. Patients ranged in age at the time of diagnosis from 8 to 74 years (mean: $38.20 \pm 16.71$ ). KCOTs had a peak of occurance in the third and fifth decade of life (23.4\%-20.3\%) (Table-1). Postoperative follow up period was 3-8 years (mean time $4.76 \pm 1.10$ ). The all manbibular to maxillary ratio of tumor occurance was 3.27:1.

Table-1. Distribution of Age and Gender.*

\begin{tabular}{cccc}
\hline Age & Male (\%) & Female (\%) & Total (\%) \\
\hline $0-9$ & $1(1.6)$ & $0(0)$ & $1(1.6)$ \\
$10-19$ & $4(6.3)$ & $3(4.7)$ & $7(10.9)$ \\
$20-29$ & $8(12.5)$ & $7(10.9)$ & $15(23.4)$ \\
$30-39$ & $9(14.1)$ & $2(3.1)$ & $11(17.2)$ \\
$40-49$ & $10(15.6)$ & $3(4.7)$ & $13(20.3)$ \\
$50-59$ & $6(9.4)$ & $3(4.7)$ & $9(14.1)$ \\
$60-69$ & $4(6.3)$ & $2(3.1)$ & $6(9.4)$ \\
$70-79$ & $2(3.1)$ & $0(0)$ & $2(3.1)$ \\
\hline Total & $\mathbf{4 4 ( 6 8 . 8 )}$ & $\mathbf{2 0 ( 3 1 . 2 )}$ & $\mathbf{6 4 ( 1 0 0 )}$ \\
\hline
\end{tabular}

${ }^{\star}$ Mean age 38 , male to female ratio was 2.2:1.

Forty-nine tumors $(76.6 \%)$ located in the mandible: 36 tumors in the mandibular posterior $56.2 \%, 9$ in the anterior area $14.1 \%$, and 4 in the extend location $6.3 \%$. Fifteen tumors $(23.4 \%)$ occured in the maxilla: 11 tumors in the anterior area $17.2 \%, 2$ in the posterior area $3.1 \%$, and 2 in the maxillary extend location $3.1 \%$. Six tumors $(9.4 \%)$ were multiple form. Forty tumors $(62.5 \%)$ were presented with an impacted tooth. Forty-two tumors $(65.6 \%)$ were associated with daughter cysts (Figure-1). 


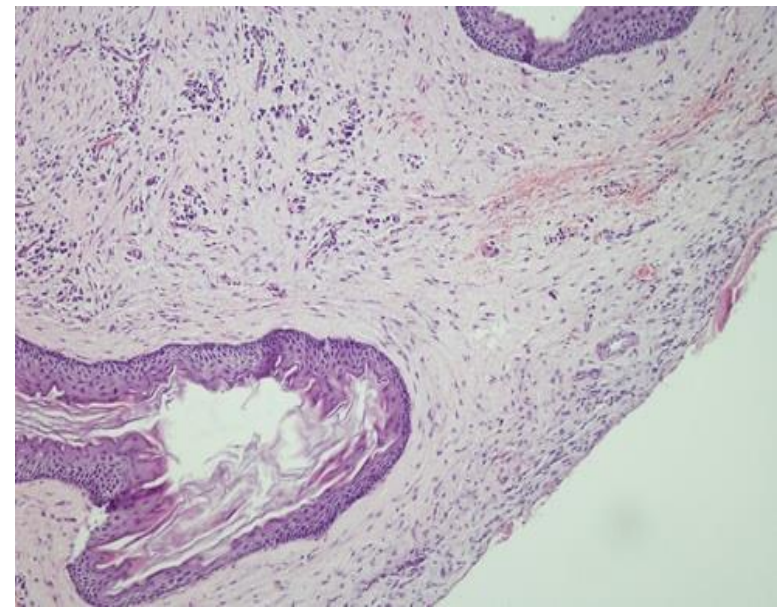

Figure-1. Prominent daughter cysts containing keratin rings (H\&E staining, orginal magnification X100).

Fifty-one tumors (79.6\%) showed parakeratinization (Figure-2) and 13 mixed parakeratinization and ortho keratinization (21.4\%). In addition, two tumors had Ruston bodies (Figure-3).

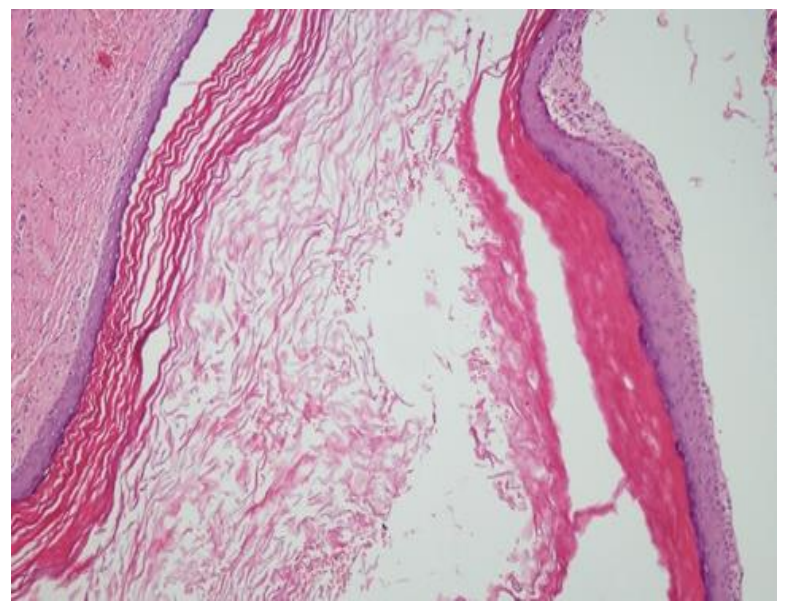

Figure-2. Grooved surface with parakeratinization (H-E staining, orginal magnification $\mathrm{X} 100$ ).

Analysis of the treatments used for the tumors showed that $44(68.7 \%)$ were treated by enucleation, $12(18.7 \%)$ by marsupialization, $1(1.6 \%)$ by marsupialization and subsequent enucleation, $1(1.6 \%)$ by enucleation and subsequent Carnoy's solution, and $6(9.3 \%)$ by enucleation and subsequent peripheral ostectomy. Nine tumors (14.1\%) were done rezidiv (Table-2).

In all recurrent cases, five (55.5\%) occured in males and four $(44.5 \%)$ in females; the male to female ratio was 1.24:1. All the recurrent cases, nine tumors (\%100) located in the mandible (Figure-4). Four recurrent cases (44.5\%) were associated with daughter cells. 7 (77.2\%) showed parakeratinization and 2 (22.8\%) mixed parakeratinization and ortho keratinization In total 9 lesions (14.1\%) recurred in two different treatments, 4 in enucleation and 5 in marsupialization.

Volume 54 Issue 2, June 2015 / Cilt 54 Sayı 2, Haziran 2015

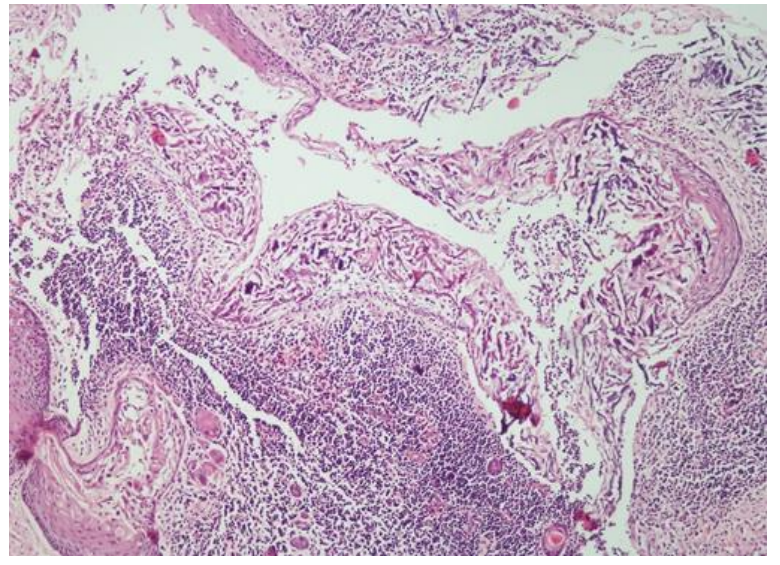

Figure-3. Presence of Ruston bodies and dystrophic calcification in the epithelial islands (H\&E staining, orginal magnification X100).

Table-2. Summary of Treatment Related to Recurrence Rate.

\begin{tabular}{lccc}
\hline \multicolumn{1}{c}{ Treatment } & Lesions & Recurrences & $\begin{array}{c}\text { Recurrence } \\
\text { rate; \% }\end{array}$ \\
\hline Enucleation & 44 & 4 & 9.1 \\
$\begin{array}{l}\text { Enucleation+ } \\
\text { Carnoy's solution }\end{array}$ & 1 & 0 & 0 \\
$\begin{array}{l}\text { Enucleation+ } \\
\begin{array}{l}\text { Peripheral } \\
\text { ostectomy }\end{array}\end{array}$ & 6 & 0 & 0 \\
$\begin{array}{l}\text { Marsupialization } \\
\text { Marsupialization+ } \\
\text { Enucleation }\end{array}$ & 12 & 5 & 41.7 \\
\hline
\end{tabular}

Four of these patients were in their twenties, two were in their thirties and sixties. One patient was in his 3th decade of life Regarding the location, KCOTs in the mandible had a higher recurrence rate than those in the maxilla (100\%-0\%). Moreover, lesions located in the mandibular molar and post-molar region tended to recur more frequently (7 out of $9,77.7 \%$ ). All recurrent cases were treated with peripheral ostectomy. After the second operation in the recurrent cases, all 9 patients did not any sign of recurrence after up to 5 years clinical and radiological follow up.

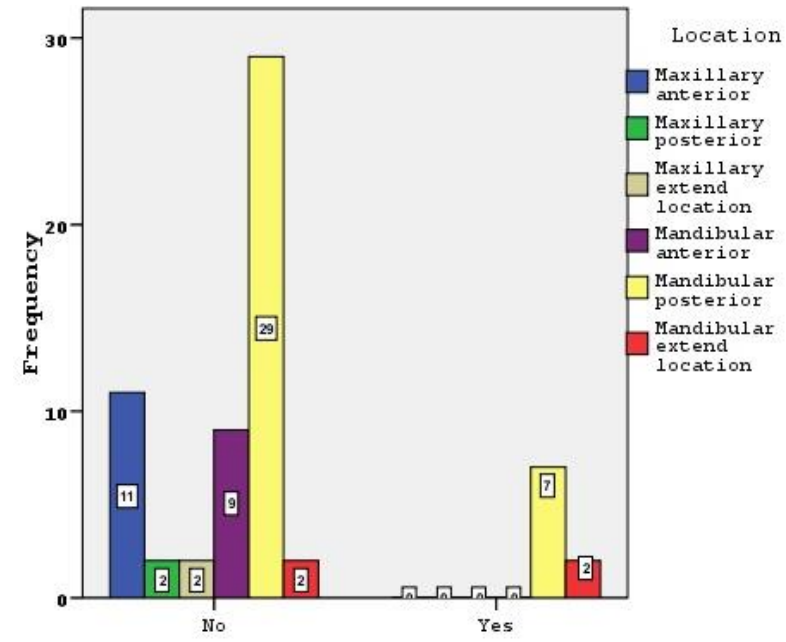

Figure-4. Distrubition of location with recurrent tumors. 


\section{Discussion}

KCOT is believed to arise from dental lamina and represents between $4-12 \%$ of all odontogenic cysts. The lesion occurs over a wide age range with a peak in the second and third decades and demonstrates a predilection for white males $(13,14)$. On the other hand, some authours found a major peak of frequency of KCOTs in the fifth and sixth decades of life (15). In the presented study, KCOTs had a peak of occurance in the third decade of life, followed by the fifth decade. Most previous studies have noted a slight male dominance $(5,8,16,17)$. Habibi et al. (7) found in a Iranian population that males were affected more often than females. Also Yagyuu et al. (18) found a male to female ratio of 1.96:1 in a series of 74 japanese cases. By contrast, Chirapathomsakul et al. (19) and Maurette et al. (20) found in their study that females were affected more often than males (male to female ratio:1:1.2/1:2.1). In our case series, we found a male to female ratio was $2.2: 1$. We confirmed a male predominance of our clinical study, as reported previously $(8,16,17,21,22)$.

KCOTs are mostly located in the mandible, especially in the posterior portion of the mandible, and in the mandibular ramus, and generally releated with unerupted teeth $(10,22,23-25)$. In our series, the KCOTs occured more frequently in the mandible than in the maxilla $(76.6 \%$ vs $23.4 \%)$. The posterior regions of the mandible were the most frequently involved part of bone with unerupted teeth, the findings being in close agreement with those of other reports $(17,26,27)$.

The incidence of daughter cysts is reported to range between $7 \%$ and $30.1 \quad(22,28)$. Some clinicians believed that the histopathological presence of daughter cysts wall may result in a report by Myoung et al. (21) where the presence of one or more daughter cysts showed a statistically significant higher recurrence rate. It is noteworthy that the four recurrent cases were associated with daughter cells in our cases. The presence of one or more daughter cysts adjacent to the cystic wall of the tumor was demonstrated in \%65.6 of lesions, which is considerably higher than reported previously. Reports of Ruston bodies within KCOT are scarce, the incidence ranging from $7 \%$ to $32 \%$ respectively $(29,30)$. We found a lower incidence (3.1\%) than reported previously $(29,30)$.

Some authors have classified KCOTs in to parakeratotic and orthokeratotic subtypes $(31,32)$. The parakeratotic type accounts fort he majority of KCOTs (83\% to $97 \%$ ) and has a greater potential for local destruction and extension in to adjacent tissues, rapid growth, recurrence, and multiplicity $(23,24)$. In our cases, $79.7 \%$ of tumors were identified parakeratinization, and $20.3 \%$ showed mixed parakeratinization and orthokeratinization.
Recurrence rates of KCOT are reported from $0 \%$ (28) to $62.5 \%(2,4,28)$. Different studies show different recurrence rates $(2,4,33)$. Most reports show that recurrence will appear with in 5 to 7 years $(12,22,27$, 29). Recurrences showed within the first 3 years in our patient group. Our $14.1 \%$ recurrence rate agrees with previous findings $(12,22,27,29)$. Five of the nine recurrent lesions were found in patients less than 30 years. This data was similar to that found by Forssell et al. (34), who reported a higher recurrence rate in young patients. In the current study, all of recurrences which occured mandible, were almost equal by gender.

The treatment of the KCOT is still controversial. Treatments are generally classified as conservative or aggressive. Conservative treatment mostly includes simple enucleation, with or without curettage, or marsupialization. Aggressive treatment generally includes peripheral ostectomy (35), chemical curettage with Carnoy's solution (36), cryotherapy with liquid nitrogen (37), or electrocautery and segmental resection $(12,28,38,39)$. In the current literatures, aggressive treatments have generally been recommended for mandibular KCOTs and recurrent lesions (38). Researchers have attempted to systematically investigate the outcomes of these procedures, however integrating data across individual studies revealed too many inconsistencies to draw definitive conclusions. The likelihood of recurrences and the ability to study theses outcomes statistically is affected by numerous variables including: subtle discrepancies in treatments, differences in the locations of the cysts, presence or absence of infection, associated teeth, involvement of mucosa, size of the lesion, and association with the Gorlin Syndrome. Because of these numerous factors, the treatment and prognosis of keratocystic odontogenic tumors must be managed in a case by case manner (39). While the cyst is a benign neoplasm, its recurrence rate may be as high as $17-56 \%$ with simple enucleation. If an adjunctive treatment is added, such as the application of Carnoy's solution or decompression before enucleation, the recurrence rate is reported to be between 1 and $8.7 \%$. Resection is uniformly reported to result in essentially no recurrences, but may be unacceptably extensive given the benign nature of the disease (39). In our study, enucleation showed a $9.1 \%$ recurrence rate, which is somewhat lower than in similar studies $(12,19,21)$. Marsupialization resulted in a $41.7 \%$ recurrence rate, which is similar to the findings reported by some researcher $(6,22)$.

\section{Conclusion}

In conclusion, although there are several studies in literature, the choice of treatment strategies remains controversial. The findings in our study that, recurrences of KCOT was more often occured in posterior mandible tended to recur more frequently. From the total of 9 
recurrences, 4 lesions were associated with daughter cysts, and 7 lesions were parakeratotic KCOT. The method of operation for these recurrent lesions should be considered as a more aggressive approach. A strict follow-up protocol for KCOT will allow for early surgical intervention in cases of recurrence and could minimize the need for second surgery. KCOTs recurrence may associated with many factors and clear link between clinical or radiological findings.

\section{References}

1. Mclvor M. The radiological features of odontogenic keratocysts. Br J Oral Surg 1972;10(2):116-25.

2. Pindborg JJ, Hansen J. Studies on odontogenic cyst epithelium. 2. Clinical and roentgenologic aspects of odontogenic keratocysts. Acta Pathol Microbiol Scand 1963;58(4):283-94.

3. Maurette PE, Jorge J, de Moraes M. Conservative treatment protocol of odontogenic keratocyst: A preliminary study. J Oral Maxillofac Surg 2006;64(3):379-83.

4. Chow HT. Odontogenic keratocyst: A clinical experience in Singapore. Oral Surg Oral Med Oral Pathol Oral Radiol Endod. 1998;86(5):573-7.

5. Philipsen HP. Keratocystic odontogenic tumour. In: Barnes L, Eweson JW, Reichart P, Sidransky D (eds). World Health Organization Classification of Tumors. Lyon: IARC Press; 2005:306-7.

6. Forssell K, Sorvari TE, Oksala EA. Clinical and radiographic study of odontogenic keratocysts in jaws. Proc Finn Dent Soc 1974;70(4):121-34.

7. Habibi A, Saghravanian N, Habibi M, Mellati E, Habibi M. Keratocystic odontogenic tumor: A 10-year retrospective study of 83 cases in an Iranian population. J Oral Sci 2007;49(3):229-35.

8. Zhao YF, Wei JX, Wang SP. Treatment of odontogenic keratocysts: A follow-up of 255 Chinese patients. Oral Surg Oral Med Oral Pathol Oral Radiol Endod 2002;94(2):151-6.

9. Gustafson G, Lindahl B, Dahl E, Svensson A. The nevoid basal cell carcinoma syndrome--Gorlin's syndrome. Multiple jaw cysts and skin cancer. Swed Dent J 1989;13(4):131-9.

10. Neville BW, Damm DD, Allen CM, Bouquot JE. Oral and Maxillofacial Pathology. 2nd ed. Philadelphia: Saunders; $2002: 595$.

11. Gorlin RJ, Vickers RA, Kellen E, Williamson JJ. Multiple basal-cell nevi syndrome. An analysis of a syndrome consisting of multiple nevoid basal-cell carcinoma, jaw cysts, skeletal anomalies, medulloblastoma, and hyporesponsiveness to parathormone. Cancer 1965;18(2):89-104.

12. Morgan TA, Burton CC, Qian F. A retrospective review of treatment of the odontogenic keratocyst. J Oral Maxillofac Surg 2005;63(5):635-9.

13. Barnes L, Eveson JW, Reichart P, Sidransky D. World Health Organization Classification of Tumors: Pathology and Genetics of Head and Neck Tumors. Lyon: IARC Press;2005.

14. Thompson L, Goldblum J. Head and Neck Pathology: A Volume in the Series Foundations in Diagnostic Pathology. Philadelphia: Elsevier;2006.

15. Kakarantza-Angelopoulou E, Nicolatou O. Odontogenic keratocysts: Clinicopathologic study of 87 cases. J Oral Maxillofac Surg 1990;48(6):593-9.

16. Brannon RB. The odontogenic keratocyst. A clinicopathologic study of 312 cases. Part I. clinical features. Oral Surg Oral Med Oral Pathol 1976;42(1):54-72.

17. Crowley TE, Kaugars GE, Gunsolley JC. Odontogenic keratocysts: A clinical and histologic comparison of the parakeratin and orthokeratin variants. J Oral Maxillofac Surg 1992;50(1):22-6.

18. Yagyuu T, Kirita T, Sasahira T, Moriwaka Y, Yamamoto K, Kuniyasu H. Recurrence of keratocystic odontogenic tumor: Clinicopathological features and immunohistochemical study of the hedgehog signaling pathway. Pathobiology 2008;75:171-6.

19. Chirapathomsakul D, Sastravaha P, Jansisyanont P. A review of odontogenic keratocysts and the behavior of recurrences. Oral Surg Oral Med Oral Pathol Oral Radiol Endod 2006;101(1):5-9

20. Maurette PE, Jorge J, de Moraes M. Conservative treatment protocol of odontogenic keratocyst: a preliminary study. J Oral Maxillofac Surg 2006;64(3):379-83.

21. Myoung H, Hong SP, Hong SD, et al. Odontogenic keratocyst: Review of 256 cases for recurrence and clinicopathologic parameters. Oral Surg Oral Med Oral Pathol Oral Radiol Endod 2001;91(3):328-33.

22. Ahlfors E, Larsson A, Sjögren S. The odontogenic keratocyst: A benign cystic tumor? J Oral Maxillofac Surg 1984;42(1):10-9.

23. Güler N, Sençift K, Demirkol O. Conservative management of keratocystic odontogenic tumors of jaws. Scientific World Journal 2012;2012:680397. doi: 10.1100/2012/680397.

24. MacDonald-Jankowski DS. Keratocystic odontogenic tumour: Systematic review. Dentomaxillofac Radiol 2011;40(1):1-23.

25. Titinchi F, Nortje CJ. Keratocystic odontogenic tumor: A recurrence analysis of clinical and radiographic parameters. Oral Surg Oral Med Oral Pathol Oral Radiol 2012;114(1):136-42.

26. Stoelinga PJ. Long-term follow-up on keratocysts treated according to a defined protocol. Int J Oral Maxillofac Surg 2001;30(1):14-25.

27. el-Hajj G, Anneroth G. Odontogenic keratocysts--a retrospective clinical and histologic study. Int J Oral Maxillofac Surg 1996;25(2):124-9.

28. Bataineh AB, al Qudah M. Treatment of mandibular odontogenic keratocysts. Oral Surg Oral Med Oral Pathol Oral Radiol Endod 1998:86(1):42-7.

29. Lam KY, Chan AC. Odontogenic keratocysts: A clinicopathological study in Hong Kong Chinese. Laryngoscope 2000;110(8):1328-32.

Volume 54 Issue 2, June 2015 / Cilt 54 Sayı 2, Haziran 2015 
30. Woolgar JA, Rippin JW, Browne RM. The odontogenic keratocyst and its occurrence in the nevoid basal cell carcinoma syndrome. Oral Surg Oral Med Oral Pathol 1987;64(6):727-30.

31. Haring JI, Van Dis ML. Odontogenic keratocysts: A clinical, radiographic, and histopathologic study. Oral Surg Oral Med Oral Pathol 1988;66(1):145-53.

32. Som PM, Curtin HD. Chronic inflammatory sinonasal diseases including fungal infections. The role of imaging. Radiol Clin North Am 1993;31(1): 33-44.

33. Godhi SS, Kukreja P. Keratocystic odontogenic tumor: A review. J Maxillofac Oral Surg 2009;8(2):127-31.

34. Forssell K, Forssell H, Kahnberg KE. Recurrence of keratocysts. A long-term follow-up study. Int J Oral Maxillofac Surg 1988;17(1):25-8.

35. Ghali GE, Connor MS. Surgical management of the odontogenic keratocyst. Oral Maxillofac Surg Clin North Am 2003;15(3):38392.

36. Stoelinga PJ. The treatment of odontogenic keratocysts by excision of the overlying, attached mucosa, enucleation, and treatment of the bony defect with carnoy solution. J Oral Maxillofac Surg 2005;63(11):1662-6.

37. Schmidt BL. The use of liquid nitrogen cryotherapy in the management of the odontogenic keratocyst. Oral Maxillofac Surg Clin North Am 2003;15(3):393-405.

38. Meiselman F. Surgical management of the odontogenic keratocyst: Conservative approach. J Oral Maxillofac Surg 1994;52(9):960-3.

39. Blanas N, Freund B, Schwartz M, Furst IM. Systematic review of the treatment and prognosis of the odontogenic keratocyst. Oral Surg Oral Med Oral Pathol Oral Radiol Endod 2000;90(5):553-8. 